D P S T - 84 - 334

\title{
TECHNETIUM-99 IN SRP HIGH-LEVEL WASTE AND SALTSTONE
}

b y

J.R. Fowler, B.A. Hamm, and J.R. Cook

E. I. du Pont de Nemours \& Company

Savannah River Plant

Aiken, South Carolina 29808

This report was prepared in connection with work done under Contract No.

DE-AC09-81SR0001 with the U.S. Department of Energy. By acceptance of this report, the publisher and/or recipient acknowledges the U.S. Government's right to retain a nonexclusive, royalty-free license in and to any copyright covering this report, along with the right to reproduce and to authorize others to reproduce all or part of the copyrighted report.

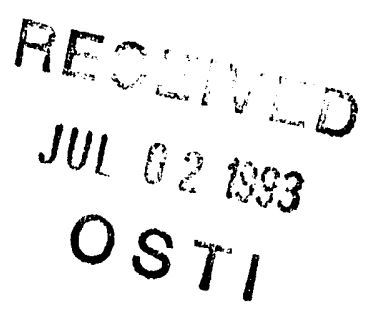




\section{DISCLAIMER}

This report was prepared as an account of work sponsored by an agency of the United States Government. Neither the United States Government nor any agency thereof, nor any of their employees, makes any warranty, express or implied, or assumes any legal liability or responsibility for the accuracy, completeness, or usefulness of any information, apparatus, product, or process disclosed, or represents that its use would not infringe privately owned rights. Reference herein to any specific commercial product, process, or service by trade name, trademark, manufacturer, or otherwise does not necessarily constitute or imply its endorsement, recommendation, or favoring by the United States Government or any agency thereof. The views and opinions of authors expressed herein do not necessarily state or reflect those of the United States Government or any agency thereof.

This report has been reproduced directly from the best available copy.

Available to DOE and DOE contractors from the Office of Scientific and Technical Information, P. O. Box 62, Oak Ridge, TN 37831; prices available from (615) $576-8401$.

Available to the public from the National Technical Information Service, U. S. Department of Commerce, 5285 Port Royal Rd., Springfield, VA 22161. 
TECHNICAL DIVISION

SAVANNAH RIVER LABORATORY
CC: W. R. Stevens, III, 773-A

R. M. Wallace, 773-A

R. B. Ferguson, 773-A

M. D. Boersma, 704-T

M. A. Ebra, 773-A

M. J. Plodinec, 773-A

E. L. Wilhite, 773-A

G. T. Wright, 773-A

J. P. Bibler, 773-A

R. E. Edwards, 704-T

W. G. Holmes, 773-18A

L. F. Landon, 704-T

D. D. Walker, 773-A

SRL Records (4), 773-A

PMC File, 773-A

ACC.NO.

$1+402$

$14 / 122$

Eebruary 24, 1984

TO: G.W. WILDS/ E. L. ALBENESIUS

FROM : J. R. FOWLER, B. A. HAMM, J. \&. COOK



B.A. Hanm

TECHNETIUM-99 IN SRP HIGH-LEVEL WASTE AND SALTSTONE

\section{SUMMARY}

Analyses of sludge and soluble waste samplesl-3 and the inventory of sludge 4 and soluble waste 5,6 have been used to estimate the concentration of technetium-99 (TC-99) in sludge solids and soluble waste. These data were also used to establish if the source term assumptions for TC-99 in the Defense Waste Processing Facility (DWPF) flowsheet are accurate and determine the fraction of the Tc-99 inventory in the waste that is soluble. This analysis was needed to establish if the present basis for decontaminated salt feed to the saltstone process is correct.7 These results and the projected leach rate for Tc-99 from saltstone can then be used to establish if Tc-99 must be removed from contaminated supernate.

Results show:

- The inventory of TC-99 is $31,050 \mathrm{Ci}$ in sludge and soluble waste. 
G. W. WILDS, et.al. $\quad-2-\quad \begin{array}{ll}\text { DPST-84-334 } \\ \text { February 24, } 1984\end{array}$

- "Average" dissolved salt feed to saltstone will contain $0.096 \mathrm{mCi} /$ liter $(400 \mathrm{~g}$ salt/liter $\mathrm{x} 240 \mathrm{nCi} / \mathrm{g}$ salt) without $\mathrm{TC}$ removal. This level corresponds to $74 \mathrm{nCi} / \mathrm{g}$ of solution and is a factor of $2.4 \mathrm{X}$ higher than previously assumed.

- The higher Tc-99 concentration is approximately an order of magnitude lower than the limit imposed by EPA regulations; TC removal is not required.

- The source term calculated from experimental data agrees well with the source term calculated from fission yield in the present DWPF flowsheet.

- Approximately $57 \%$ of the Tc-99 is soluble compared to $30 \%$ previously assumed.

\section{INTRODUCTION}

An in-tank process based on precipitation of cesium tetraphenylborate effectively removes radioactive cesium from soluble waste 3,8 . The major long-lived radionuclide remaining in the decontaminated Eiltrate from this process is TC-99, a weak beta-emitter with a halflife of $2.13 \mathrm{E5}$ years.3 Methods to remove Tc-99 from decontaminated salt solution have been developed if removal is required or desired.9-12 An estimate of the Tc-99 waste inventory based on experimental data was needed to establish if Tc-99 should be removed from the salt solution before converting it to saltstone.

\section{DISCUSSION}

\section{A. Source of TC-99 in SRP Waste}

Tc-99 is a fission product in spent fuel and targets from the SRP and off-site reactors. The source term used in the DWPF flowsheet for Tc-99 is based on fission yield calculations from an assumed mix of depleted uranium targets, enriched uranium fuel tubes from SRP reactors and spent fuel from cff-site reactors.

All of the Tc-99 present in these fuels and targets is assumed to be diverted to the waste tanks as a result of processes in the separations Areas. Because of the diversity of materials that have been processed at SRP and assumptions on splits in the separation Areas, the source term shown in the DWPF flowsheet for Tc-99 (or any other fission product) may not accurately reflect the actual inventory of fission products in the waste.14

During processing in the separation Areas, nitric acid oxidizes TC to higher oxidation states. None of the isotopes of Tc are stable with respect to nuclear decay. Consequently, Tc does not occur in nature and the chemistry of TC has not been extensively studied except at nuclear sites. 

G. W. WILDS, et.al.
$-3-$
DP ST $-84-334$
February 24,1984

Table I shows probable reactions for Tc during fuel dissolution with nitric acid. Tc has been found in both soluble and insoluble components of SRP waste. Available data show that hydrated technetium(IV) oxide is the most likely species in the sludge while sodium pertechnetate is the most likely species in the soluble salt. 12

\section{B. Tc-99 in Soluble waste}

Tc-99 analyses have been done on several SRP soluble waste samples.1-3 Available data for soluble waste were averaged to establish the concentration of Tc-99 in each of the waste types (Table II). Using these averages and the estimated inventory of soluble waste, 5,6 the total inventory of Tc-99 in the soluble waste was calculated. The concentration of Tc-99 in "average" salt is $240 \mathrm{nCi} / \mathrm{g}$ of salt. Results from these calculations are shown in Table III.

\section{Tc-99 in sludge}

Calculations for sludge were similar to those used for soluble waste. Available datal,2 for sludge samples were averaged to establish the concentration of TC-99 in each type of sludge presently stored in the tank farm (Table IV). Using these averages and the estimated sludge inventory, 4 the total inventory of TC-99 in sludge was calculated. The concentration of TC-99 in "averagen sludge is 4470 $\mathrm{nCi} / \mathrm{g}$ of dry sludge solids. Results for these calculations are shown in Table $V$.

\section{Tc-99 Source Term for the DWPF Flowsheet}

Source terms for fission products in the DWPF flowsheet are based on "as-received, average" waste that is allowed to age either 5 or 15 years without regard to any segregation between soluble and insoluble waste components (see A. above for additional bases). Each galion of "average" waste is assumed to contain 2.944 lbs of salt ( $1336 \mathrm{~g} / \mathrm{gal})$ and 0.145 lbs of insoluble solids $(65.8 \mathrm{~g} / \mathrm{gal}) .14$

Using these values for "average" waste and the average Tc-99 concentrations shown in Tables II and III for salt and sludge, the Tc-99 source term and the soluble fraction were calculated for the DWPF flowsheet. Results of these calculations are shown in Table VI. The source term obtained from experimental data is comparable to the value obtained from fission yield calculations, but the fraction soluble is approximately double the value previously assumed for the DWP flowsheet.7 Accordingly, the solubility factor used in the flowsheet should be changed to reflect more of the Tc-9g being diverted to the soluble waste. 

G. W. WILDS, et.al.
DP ST-84-334
February 24,1984

E. Tc-99 in Decontaminated Soluble Waste

The flowsheet for the "Saltstone" process assumes that 32 wt8 solution of decontaminated salt in water will be combined with cement to produce "Saltstone".13 The density of 32 wts solution of "average" salt is $1.27 \mathrm{~kg} / \mathrm{liter}$ and would contain approximately $400 \mathrm{~g}$ of salt/liter. 7

Based on an average concentration of Tc-99 equal to $240 \mathrm{nCi} / \mathrm{g}$ of dry salt (see Table II), feed to saltstone would contain $0.096 \mathrm{mCi}$ Tc-99/ liter of solution $(0.36 \mathrm{mCi} / \mathrm{galion})$. Based on the density of "average" salt solution, $74 \mathrm{nCi}$ of $\mathrm{Tc}-99$ would be present in each gram of decontaminated solution. This level is 2.4 times higher than previously assumed. $7,1 \overline{3}$

\section{F. Tc-99 from Saltstone}

The latest mathematical modeling work done by Intera Environmental Consultants indicates that with the current saltstone formulation the concentration of TC-99 in groundwater should be $45 \mathrm{pCi} / \mathrm{Titer}$, using the old source term. Increasing the source term by a factor of 2.4 increases the groundwater concentration to $110 \mathrm{pCi} / \mathrm{liter}$, which is almost an order of magnitude below the EPA National Primary Drinking Water Regulation limit of $900 \mathrm{pCi} / 1$ iter. Thus the present saltstone formulation will prevent the increased $T C$ in the feed solution from adversely affecting the environment.

\section{QUALITY ASSURANCE}

Data used in these calculations is the best available at the time of writing. Additional sampling and analyses of the waste tanks is planned to broaden the data base for TC-99 in the waste. When necessary, blind controls will be submitted with these new samples to assure that the quality of data is maintained. These calculations will be updated as required when additional data is available.

JRF : pm C

Att

12 

G. W. WIILDS, et.al.

\section{REFERENCES}

1. J. R. FOWLER, DPSTN-3302, Pp 69 .

2. B. A. Hamm, Record Books 1, 2, and 3 .

3. WALKER, D. D. and HAMM, B. A., "Sample Analyses from the Full Scale In-Tank Demonstration of the Precipitation Process," DP ST-83-695, September 2, 1983.

4. EIBLING, R. E. and FOWLER, J. R., "Updated waste composition at The Savannah River Plant," DPST-83-313, March 1983.

5. FOWLER, J. R., "Calculated Composition of F Area Soluble High Level Waste", DPST-82-390, March 10, 1982.

6. FOWLER, J. R., "Calculated Composition of H Area and SRP Soluble High Level Waste", DPST-82-502, April 28, 1982.

7. FOWLER, J. R., "Update of Chemical and Radiochemical Composition of Decontaminated Soluble waste from the Precipitation Process," DPST-82-759, August 6, 1982 .

8. SNELL, E. B. and HENG, C. J., "Salt Decontamination Demonstration Test Results," DP SP-83-17-8, June 20, 1983.

9. WALKER, D. D., "Technetium Precipitation Process," DPST-83-331, February $25,1983$.

10. WALKER, D. D., "Technetium Precipitation Process (Part 2)," DP ST-83-998, November 10, 1983.

11. WALKER, D. D., "Ion Exchange Removal of Technetium from Salt Solutions," DPST-83-1048, December 2, 1983.

12. J. P. Bibler, DP STN-4185.

13. "Technical Data Summary - Decontaminated Salt Disposal as Saltcrete in a Landfill," DPSTD-82-65, Revision 1, December 21, 1982.

14. LANDON, L. F., and THOMPSON, T. T., compilers, "Technical Data Summary for the Defense Waste Processing Facility: Stage 1 (DPSTD-80-38-2) and Stage 2 (DPSTD-80-39-2)".

15. TURCOTTE, M-D. S., and KING, C. M., "Environmental Implications of Tc-99 - DWPF Operations and Saltcrete," DPST-82-608, March 17, 1983. 
G. W. WILDS, et.al.

$\begin{array}{ll}-6- & \text { DP ST-84-334 } \\ \text { February } 24,1984\end{array}$

\section{TABLE I}

\section{PROCESS CHEMISTRY FOR TECHNETIUM IN F AND H AREAS}

$$
\begin{gathered}
3 \mathrm{TC}+4 \mathrm{HNO}_{3}=3 \mathrm{TCO}_{2}+4 \mathrm{NO}+2 \mathrm{H}_{2} \mathrm{O} \\
\mathrm{TCO}_{2}+\mathrm{HNO}_{3}=\mathrm{HTCO}_{4}+\mathrm{NO} \\
\mathrm{HTCO}_{4}+\mathrm{NaOH}=\mathrm{NaTCO}_{4}+\mathrm{H}_{2} \mathrm{O}
\end{gathered}
$$

- TC present in both sludge and supernate. 

G. W. WILDS, et.al.
DP ST $-84-334$
February 24, 1984

\section{TABLE II}

DESCRIPTION AND ANALYSES OF SOLUBLE WASTE SAMPLES

SAMPLE

TYPE

POREX HAW:

PUREX LAW

PUREX LAW

PUREX LAW

PUREX LAW

PUREX LAW

PUREX LAW

PUREX LAW

POREX LAW AVERAGE:

PUREX CONC. SN:

PUREX SALT

PUREX SALT

DISS. PUREX SALT

DISS. PUREX SALT

PUREX SALT AVERAGE:

BM BAW :

BM LAW :

EM CONC. SN:

HM SALT

HM SALT

DISS. HM SALT

DISS. HM SALT

DISS. HM SALT

DISS. HM SALT

DISS. HM SALT

DISS. HM SALT

BM SALT AVERAGE:

SOURCE, g SALT/liter

172

225

$185^{\prime}$

122

273

273

273

273

$8 \mathrm{~F}$

$47 \mathrm{~F}$

$1 \mathrm{~F}$

$19 \mathrm{~F}$

$20 \mathrm{~F}$

$32 \mathrm{H}$

138

$30 \mathrm{~B}$

$9 \mathrm{H}$

$10 \mathrm{H}$

$24 \mathrm{H}$

$24 \mathrm{H}$

$24 \mathrm{H}$

$24 \mathrm{H}$

$24 \mathrm{H}$

$24 \mathrm{H}$

668

N.A. (b)

N.A.

296

$55 \%$

388

$593(c)$

1139

N.A.

N.A.

444

593

575

420

470

388
[TC-99] nCi/g SALT REF/METHOD (a)

680

$2 / \mathrm{B}$

160

200

180

110

100

110

110

$2 / \mathrm{H}$

$2 / \mathrm{H}$

$2 / \mathrm{H}$

$2 / \mathrm{H}$

$2 / \mathrm{H}$

$2 / \mathrm{H}$

$2 / \mathrm{H}$

140

430

$1 / \mathrm{H}$

$1 / \mathrm{H}$

20

160

20

60

$1 / \mathrm{H}$

$1 / \mathrm{H}$

$1 / \mathrm{H}$

60

620

$1 / N$

670

$1 / \mathrm{B}$

360

$1 / N$
$1 / \mathrm{N}$

$1 / \mathrm{N}$

$1 / \mathrm{H}$

$1 / \mathrm{H}$

$1 / \mathrm{H}$

$3 / \mathrm{H}$

$3 / \mathrm{H}$

$3 / \mathrm{H}$

80

(a) $\mathrm{H}=$ Hanford Method; $\mathrm{N}=$ Neutron Activation Analysis Method.

(b) Nigh salt level indicates this sample is a blend of conc. SN and HM LAW placed in Tank $13 \mathrm{H}$ for feeding the waste evaporator. 
G. W. WILDS, et.al. $\quad-8-\quad \begin{array}{ll}\text { DPST }-84-334 \\ \text { February 24, } 1984\end{array}$

TABLE III

INVENTORY OF SOLUBLE TC-99 IN THE WASTE TANKS

WASTE

COMPONENT

H-AREA :

HM HAW SN

HM LAW SN

HM CONC. SN

HM SALT

AI DISS. ADD'N

H-AREA SOLUBLE WASTE

F-AREA :

PUREX HAW SN

PUREX LAW SN

COATING WASTE

PUREX CONC. SN

PUREX SALT

F-AREA SOLUBLE WASTE

TOTAL SOLUBLE WASTE
INVENTORY

MET. TONS

4900

4400

11000

19000

1800

41100

800

2500

1100

14000

21000

39400

80500
[ TC-99]

$\mathrm{nCi} / \mathrm{g}$

620

670

360

80

$---$

$290 \mathrm{nCi} / \mathrm{g} \quad 11470$

680

140

$-$

430

60

$280 \mathrm{nCi} / \mathrm{g}$

$240 \mathrm{nCi} / \mathrm{g} \quad 19640$
8170

3040

2950

3960

1520

- -

540

350

$--$

6020

1260 

G. W. WILDS, et.al.
DP ST $-84-334$
February 24, 1984

\section{TABLE IV}

\section{DESCRIPTION AND ANALYSES OF SLUDGE SAMPLES}

[TC-99]

SAMPLE
TYPE
PUREX HAW
PUREX LAW
PUREX LAW
PUREX LAW
PUREX LAW
PUREX LAW
PUREX LAW
PUREX LAW
PUREX LAW
PUREX LAW
PUREX LAW
PUREX LAW
PUREX LAW
PUREX LAW

SOURCE

$4 \mathrm{~F}$

$8 \mathrm{~F}$

$8 \mathrm{~F}$

$8 \mathrm{~F}$

$8 \mathrm{~F}$

$8 \mathrm{~F}$

$8 \mathrm{~F}$

$8 \mathrm{~F}$

$8 \mathrm{~F}$

$8 \mathrm{~F}$

$8 \mathrm{~F}$

$8 \mathrm{~F}$

$8 F$

$8 \mathrm{~F}$

PUREX LAW SLUDGE AVERAGE:

HM HAW (38 SAMPLES)

15B, 11H

138

$\frac{n C i / g \text { SLUDGE }}{2090}$

280

580

190

410

1100

400

1100

770

210

240

1900

1100

1090

720

8340

1640
REE/METHOD*

$2 / \mathrm{B}$

$2 / \mathrm{H}$

$2 / \mathrm{H}$

$2 / \mathrm{H}$

$2 / \mathrm{H}$

$2 / \mathrm{H}$

$2 / \mathrm{H}$

$2 / \mathrm{H}$

$2 / \mathrm{H}$

$2 / \mathrm{H}$

$2 / \mathrm{H}$

$2 / \mathrm{H}$

$2 / \mathrm{H}$

$2 / \mathrm{H}$

$2 / \mathrm{B}, 1 / \mathrm{B}$

$1 / \mathrm{B}$

* $\mathrm{H}=$ Hanford Method 

G. W. WILDS, et.al.
$-10-$
DP ST $-84-334$
February 24,1984

TABLE V

INVENTORY OF TC-99 IN SLUDGE SOLIDS

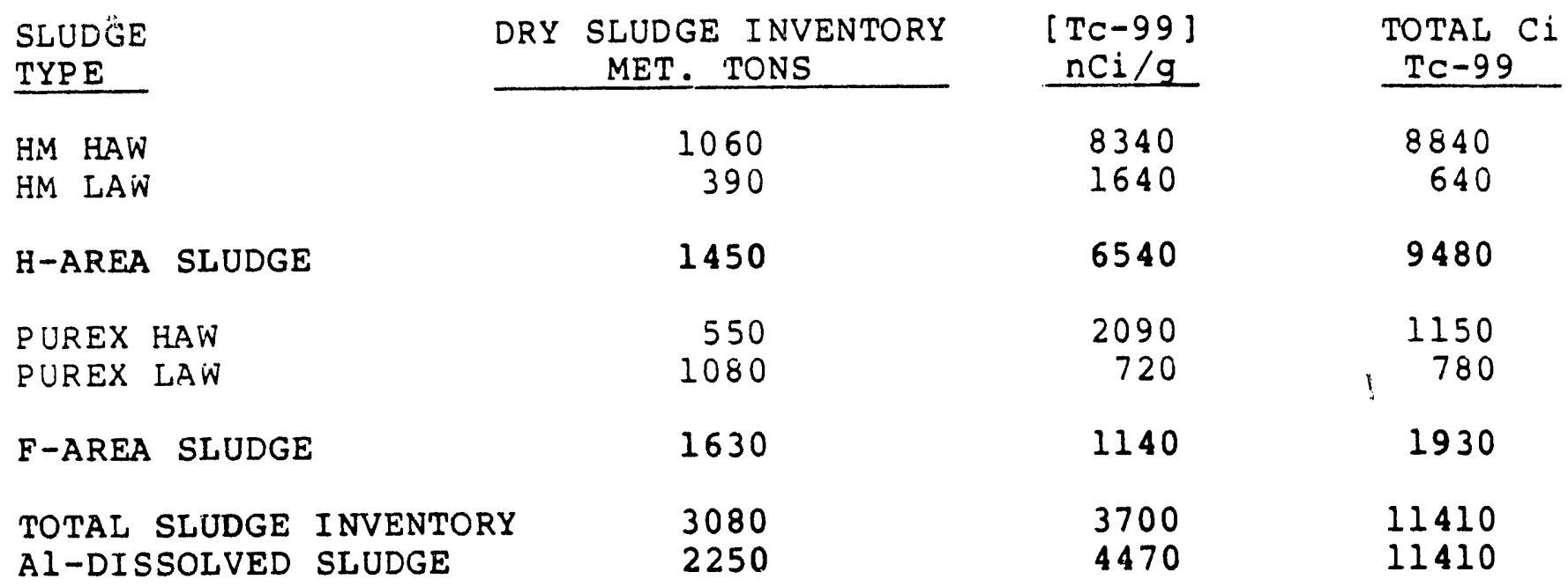

- Total inventory of Tc-99 (sludge + salt) $=31050 \mathrm{Ci}$. 


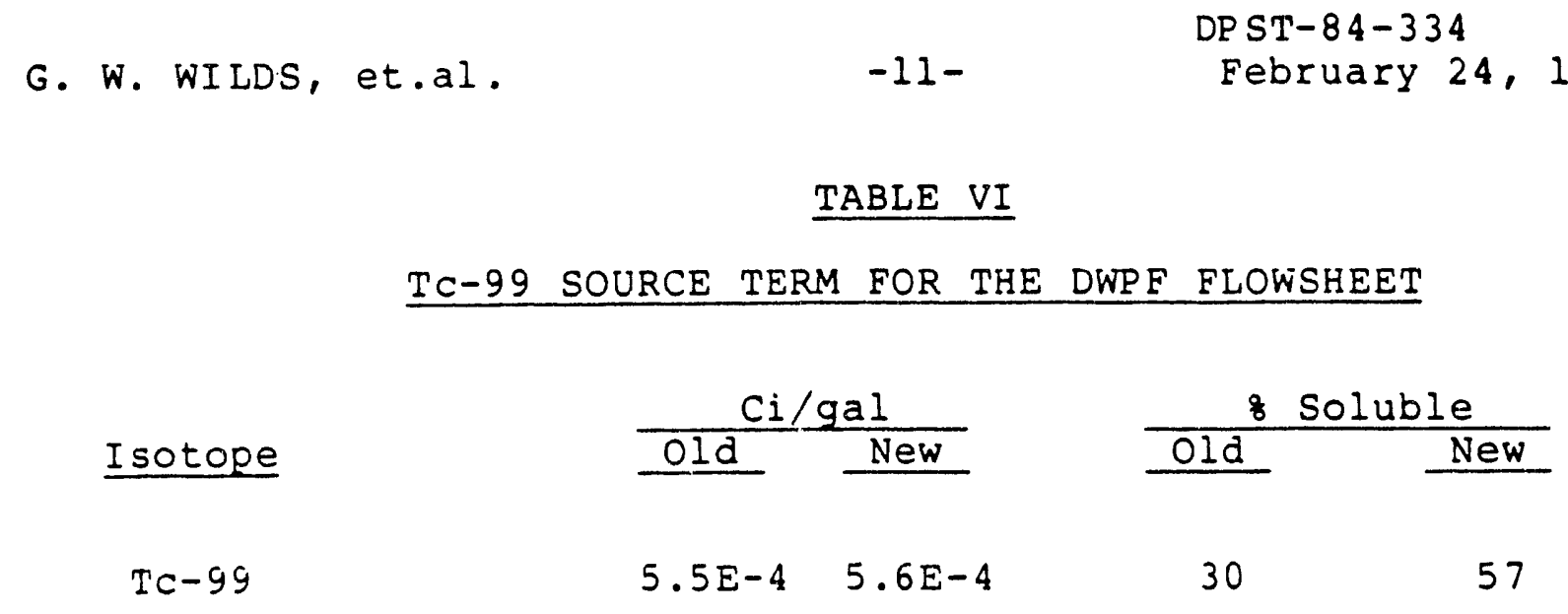



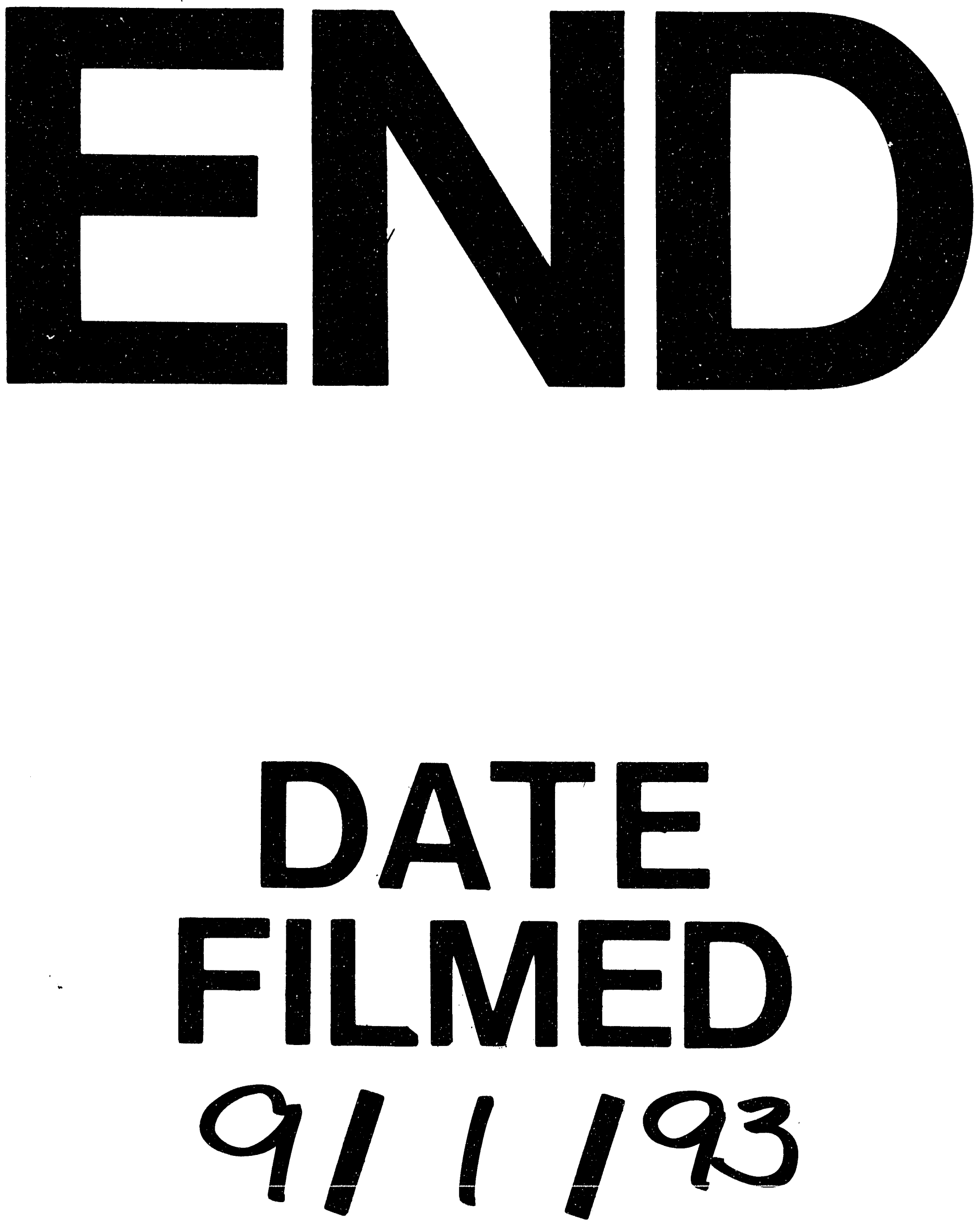
